\title{
Insight into Atrial Fibrillation in LVAD Patients: From Clinical Implications to Prognosis
}

\author{
Nicolò Sisti Giulia Elena Mandoli Carlotta Sciaccaluga Serafina Valente \\ Sergio Mondillo Matteo Cameli
}

Department of Cardiovascular Diseases, University of Siena, Siena, Italy

\section{Keywords}

Atrial fibrillation - Left ventricular assist devices · Advanced heart failure · Heart

transplantation

\begin{abstract}
The use of left ventricular assist devices (LVADs), whether for destination therapy or bridge to transplantation, has gained increasing validation in recent years in patients with advanced heart failure. Arrhythmias can be the most challenging variables in the management of such patients but the main attention has always been focused on ventricular arrhythmias given the detrimental impact on mortality. Nevertheless, atrial fibrillation (AF) is the most common rhythm disorder associated with advanced heart failure and may therefore characterize the LVADs' pre- and postimplantation periods. Indeed, the consequences of AF in the population suffering from standard heart failure may require a more comprehensive evaluation in the presence of or in sight of an LVAD, making the AF clinical management in these patients potentially complex. Several studies have been based on this subject with different and often conflicting results, leaving many questions unresolved. The purpose of this review is to summarize the main pieces of evidence about the clinical impact of AF in LVAD patients, underlining the main implications in terms of hemodynamics, thromboembolic risk, bleeding and prognosis. Therapeutic considerations about the clinical management of these patients are also made according to the latest evidence.

(c) 2020 S. Karger AG, Basel
\end{abstract}




\begin{tabular}{l|l}
\hline Pulse 2020;8:2-14 \\
\hline DOI: 10.1159/000506600 & $\begin{array}{l}\text { @ 2020 S. Karger AG, Basel } \\
\text { www.karger.com/pls }\end{array}$ \\
\hline
\end{tabular}

\section{Introduction}

Left ventricular assist devices (LVADs) are being increasingly implanted in end-stage heart failure (HF) following precise indications [1]. While epidemiology and management of ventricular arrhythmias are well documented, there are weak pieces of evidence about the epidemiology, frequency and implications of supraventricular arrhythmias in LVAD patients or candidates, in particular atrial fibrillation (AF). Atrial arrhythmias can be responsible for severe symptoms and outcomes even in well-programmed devices, and their prevalence in LVAD recipients ranges from 21 to $50 \%$. Data about the incidence of AF in the pre- and postoperative settings are different, and several details about its prognostic role and management have not been clarified yet [2-4]. Since LVAD patients face a relevant series of complications and mortality remains high despite hemodynamic support, knowledge of AF implications can lead to an improvement of the success rate of standard therapeutic strategies. This review is aimed at summarizing the main evidence about the clinical significance of AF in patients waiting for LVAD or who have already undergone implantation, with a focus on the effects on complications, management and prognosis.

\section{AF in Advanced HF}

Advanced HF (NYHA class IIIb-IV), as recently redefined by the Heart Failure Association of the European Society of Cardiology, represents an estimated 1-10\% of the overall HF population [1]. Prognosis in advanced HF is grave with a 1-year mortality in NYHA class III-IV patients $>25$ and $>50 \%$ in class IV [5]. AF is a worldwide epidemic involving nearly $50 \%$ of patients with advanced HF [6]. Some meta-analyses have shown that coexistence of HF and AF is associated with higher all-cause mortality over time compared with those with single disease, and the worse prognosis is independent from the severity of systolic dysfunction [7-10]. In detail, the original Framingham Heart Study showed that in 1,737 individuals, 37\% of de novo AF was in patients with HF, while $57 \%$ of de novo HF was in patients with AF [11]. The risk of stroke, hospitalization, dementia, kidney failure, myocardial infarction and death is higher when both diseases coexist [11]. AF is responsible for the loss of both atrioventricular synchrony and atrial systole, for reduced ejection time when ventricular response is high and for irregularity of ventricular contraction, with consequent progressive deterioration of cardiac performance [12]. On the other hand, systolic LV dysfunction is associated with atrial structural and electrical remodeling, secondary to increased left atrial filling pressures, which promotes and sustains AF [13-15]. According to an in vivo study by Burashnikov et al. [16], mild electrical and structural remodeling of the left atrium (LA) in the evolution of HF represents a temporal window of vulnerability predisposing to $\mathrm{AF}$ development. $\mathrm{AF}$ incidence increases in parallel with functional HF severity ( $5 \%$ in NYHA I up to 50\% in NYHA IV), but functional class does not have a linear correspondence with the entity of remodeling [16]. From a clinical point of view, AF can worsen symptoms of HF, and, in turn, decompensated HF can aggravate AF leading to rapid ventricular response [4]. The SOLVD (Studies of Left Ventricular Dysfunction) trial, despite not distinguishing paroxysmal AF (PAF) from persistent $\mathrm{AF}(\mathrm{PeAF})$, confirmed that $\mathrm{AF}$ was independently associated with all-cause mortality (relative risk 1.34; 95\% confidence interval [CI] 1.12-1.62; $p=0.002$ ) and pump failure death (relative risk 1.42; 95\% CI 1.09-1.85; $p=0.01$ ) [17]. For what concerns therapeutic strategies, the AF-CHF trial demonstrated that rhythm control is not advantageous over rate control in improving prognosis when associated with standard HF medications. The most recentCASTLEAF trial evidenced instead that in patients with NYHA class II-IV, with ejection fraction $<35 \%$ under guideline-based therapy for HF, pulmonary vein isolation to treat AF is superior to medical therapy leading to a lower incidence of death from any cause or hospitalization for HF $[18,19]$.

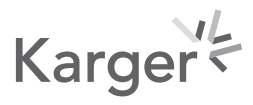




\section{General Aspects of LVADs}

Given the severe shortage of heart donors and contraindications, heart transplantation is a choice for less than $10 \%$ of patients with advanced, refractory HF [20,21]. For this reason, the use of LVAD has thus increased in recent decades (nearly 2,000 pumps are implanted annually in Europe) with the following purposes: bridge to heart transplantation, destination therapy, bridge to decision, bridge to recovery [22]. The HVAD (Heart Ware Inc., Framingham, MA, USA) and HeartMate III (Abbott Medical Australia Pty Ltd.) are centrifugal pumps while the HeartMate II (HM II, Thoratec Corp., Pleasanton, CA, USA) is an axial one. Irrespective of the design, the pump unloads the heart by pumping blood from the left ventricle through an inflow cannula and to the ascending aorta through an outflow cannula, with a flow up to 10 $\mathrm{L} / \mathrm{min}$. Duration of the device can be estimated up to 10 years $[22,23]$. The Momentum III trial has recently shown that fully magnetically levitated LVADs are less associated with pump replacement than axial-flow devices and are also superior in survival free from disabling stroke or reoperation due to malfunction [24]. No universally accepted criteria for LVAD implantation exist; however, some indicators are often used such as ejection fraction $<25 \%$, frequent or prolonged hospitalization, inability to tolerate standard HF treatments because of hypotension or renal insufficiency or reduced exercise performance [22]. Results of recent studies agree that LVAD should be considered in INTERMACS (Interagency Registry for Mechanically Assisted Circulatory Support) 3 patients, selected INTERMACS 1-2 patients and symptomatic INTERMACS 4-7 patients accepting a risk of adverse events in exchange for longer survival and better functional status [20,25]. Globally, half of implantations are performed as bridge to transplantation, and according to LVAD registries, implanted patients present an improvement of quality of life and a 1-year survival of 80\%, 2-year survival of 70\% and 5-year survival of $60 \%$ [26-28].

\section{Focus on Anticoagulation in LVAD Patients}

An upregulation of platelet activation markers and function, paving the way to increased thromboembolic events, has been demonstrated after LVAD insertion. Moreover, shear stress results in transmembrane signaling, direct platelet activation, activation of coagulation cascade. These changes together with turbulence and diminished pulsatility of blood flow lead to type 2A von Willebrand disease [3,29]. Bleeding is the most frequent adverse event in the presence of LVAD and is favored by high LVAD flows and mean arterial pressure $>90$ $\mathrm{mm} \mathrm{Hg}$ [30-32]. Pump thrombosis and arterial thromboembolism occur in approximately $8 \%$ of patients per year and may develop even in adequately anticoagulated patients [30,33]. As confirmed by Nguyen et al. [34], preoperative inflammatory status, abnormal platelet counts and higher CHA2DS2-Vasc score (at least 1 considering HF) are all risk factors for thromboembolic events, pump thrombosis and stroke. Other parameters such as advanced right ventricular failure, elevated serum creatinine, pulmonary hypertension, high or low BMI, narrow angle of inflow cannula and opening of native aortic valve must also be considered [34]. No difference has been found in the incidence of pump thrombosis or thromboembolic events among LVAD models until now [35, 36].

The supported antithrombotic therapy administered in LVAD patients is represented by aspirin and warfarin, and current guidelines support an international normalized ratio (INR) goal of 2-3 with low-dose aspirin [24, 25, 31, 37, 28]. As found by Koene et al. [39] both CHA2DS2-Vasc score and HAS-BLED score at the time of LVAD implantation manage to predict thromboembolic and bleeding events, respectively. The same authors suggest that the INR goal and/or aspirin dose should be decided according to the predominant score, and

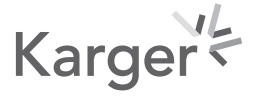


when both of them are high additional testing should be performed, such as preimplantation gastrointestinal screening or hypercoagulability testing or hematological testing. Time in therapeutic range (TTR) $>60 \%$ is considered the goal of anticoagulation management [40], although in a recent analysis the average TTR in such patients is about 42.9\% [41]. In detail, in patients with a TTR $>60 \%$ the risk of thromboembolic events is significantly lower than in patients with a TTR $<50 \%$ (hazard ratio [HR] 0.37; 95\% CI 0.14-0.96, $p=0.042$ ), and interestingly patients with TTR $>60 \%$ have also a lower relative risk for hemorrhage than the latter group (HR 0.45; 95\% CI 0.21-0.98; $p=0.045$ ) [42, 43].

\section{Hemodynamics Effects of AF in LVAD Patients}

The presence of AF, especially with high ventricular response, is a recognized cause of progressive hemodynamic compromise of the right heart with implications for the systemic output provided by LVAD [3, 4]. LVAD induces a reduction of LA size and volume index after implantation causing a reverse electro-anatomical atrial remodeling [44]. More than $40 \%$ of patients with a previous history of AF will never have a recurrence in the long-term follow-up after implantation [45]. For this reason, according to some authors, development of AF episodes after implantation may be an indirect index of inadequate mechanical support, and, consequently, AF burden together with LA volume could be noninvasive parameters for the chronic optimization of LVADs [46]. Decrease in mitral regurgitation after implantation leads to reduced atrial flow velocities and increased probability of thrombus formation [47-49]. Nearly $50 \%$ of LVAD patients show normal central venous and pulmonary capillary wedge pressure at baseline speed settings [50]. It is reported that patients with AF show even higher central venous pressure during LVAD support [51] and LVAD flow tends to be lower in AF patients than controls despite comparable LVAD speed settings [52]. The irregularity of ventricular rate, when compared with a regular rate at the same average frequency, leads to a 6-7\% reduction in cardiac output and to a significant increase in right atrial pressure and pulmonary capillary wedge pressure $[53,54]$. This hemodynamic impact of AF may be responsible for the different responses in LVAD flows when comparing LVAD patients with and without AF. Xuereb et al. [55] observed that postoperative hemodynamic parameters in patients with preoperative AF versus controls are not significantly different but $75 \%$ of patients with preoperative AF experienced aortic insufficiency after LVAD meeting criteria for surgical treatment versus $25 \%$ of no-AF patients.

\section{AF before LVAD Implantation}

Stulak et al. [56] examined the effect of preoperative AF (not distinguished in PAF or PeAF) in 389 candidates to LVAD and found no association with increased short- and longterm mortality, although preoperative AF was associated with an increased risk of thromboembolic events during a 4-year follow-up (HR 1.89; 95\% CI 1.3-2.9; $p=0.002$ ). A similar analysis was conducted on 769 patients who underwent HVAD or HM II implantation (211 in sinus rhythm and 558 with preoperative AF) and were followed up from 2006 to 2015 without differentiating the categories of AF. No significant difference was found in the incidence of pump thrombosis or thromboembolic events between the two groups, and the result was confirmed by multivariate analysis [36]. Imamura et al. [51, 52] considered 190 patients undergoing LVAD, with no differences in therapy, INR, aspirin dose or baseline characteristics except for higher age in the AF group. AF persisted after surgery in $73 \%$ of patients with preoperative AF. One-year survival free from stroke, pump thrombosis or hemorrhagic events 
Table 1. Summary of studies relating atrial fibrillation prior to implantation with thromboembolic events, bleeding and survival

\begin{tabular}{|c|c|c|c|c|}
\hline Study & $\begin{array}{l}\text { Prevalence of AF } \\
\text { prior to implantation }\end{array}$ & Thromboembolic events & Bleeding & Survival \\
\hline $\begin{array}{l}\text { Enriquez } \\
\text { et al. [4], } 2014\end{array}$ & $\begin{array}{l}55 / 106(51.9 \%, 34 \% \\
\text { PAF; } 17.9 \% \text { PeAF })\end{array}$ & $\begin{array}{l}\text { No significant difference in incidence } \\
\text { of thromboembolic events }\end{array}$ & $\begin{array}{l}\text { No significant difference } \\
\text { in incidence of bleeding, } \\
\text { type of bleeding and INR } \\
\text { levels at the time of } \\
\text { bleeding }\end{array}$ & $\begin{array}{l}\text { PeAF independent } \\
\text { predictor of death and } \\
\text { HF hospitalization }\end{array}$ \\
\hline $\begin{array}{l}\text { Pedde } \\
\text { et al. [36], } 2019\end{array}$ & $558 / 769(73 \%)$ & $\begin{array}{l}\text { No significant difference in incidence } \\
\text { of pump thrombosis, stroke, TIA or } \\
\text { embolization }\end{array}$ & & $\begin{array}{l}\text { No impact on 4-year } \\
\text { survival }\end{array}$ \\
\hline $\begin{array}{l}\text { Deshmukh } \\
\text { et al. [44], } 2017\end{array}$ & $\begin{array}{l}\text { 152/331 (46\%, 39\% } \\
\text { PAF; } 7 \% \text { PeAF) }\end{array}$ & & & $\begin{array}{l}\text { PeAF associated with } \\
\text { reduced 1-year survival }\end{array}$ \\
\hline $\begin{array}{l}\text { Imamura } \\
\text { et al. [52], } 2019\end{array}$ & $23 / 190(12 \%)$ & $\begin{array}{l}\text { No significant difference in incidence } \\
\text { of thromboembolic events }\end{array}$ & $\begin{array}{l}\text { No significant difference } \\
\text { in incidence of bleeding }\end{array}$ & $\begin{array}{l}\text { No impact on 1-year } \\
\text { survival }\end{array}$ \\
\hline $\begin{array}{l}\text { Stulak } \\
\text { et al. [56], } 2013\end{array}$ & $120 / 389(31 \%)$ & $\begin{array}{l}\text { Increased incidence of pump } \\
\text { thrombosis, stroke, TIA, hemolysis in } \\
\text { patients }<70 \text { years }\end{array}$ & & $\begin{array}{l}\text { No impact on 2-year } \\
\text { survival }\end{array}$ \\
\hline $\begin{array}{l}\text { Xia et al. } \\
{[58], 2016}\end{array}$ & $838 / 3909(21.4 \%)$ & $\begin{array}{l}\text { No significant dfference in incidence } \\
\text { of stroke, TIA, embolization, pump } \\
\text { thrombosis, hemolysis }\end{array}$ & & $\begin{array}{l}\text { No impact on 1-year } \\
\text { survival }\end{array}$ \\
\hline $\begin{array}{l}\text { Kurihara } \\
\text { et al. [59], } 2018\end{array}$ & $229 / 526(43.5 \%)$ & $\begin{array}{l}\text { No significant difference in incidence } \\
\text { of stroke }\end{array}$ & & $\begin{array}{l}\text { No impact on 2-year } \\
\text { survival }\end{array}$ \\
\hline $\begin{array}{l}\text { Koh et al. } \\
{[60], 2018}\end{array}$ & $67 / 123(54.5 \%)$ & & & $\begin{array}{l}\text { Higher mortality after } \\
\text { implantation in AF } \\
\text { patients, higher } \\
\text { incidence of right heart } \\
\text { failure after } \\
\text { implantation in PeAF }\end{array}$ \\
\hline
\end{tabular}

AF, atrial fibrillation; PAF, paroxysmal atrial fibrillation; PeAF, persistent atrial fibrillation; INR, international normalized ratio; TIA, transient ischemic attack.

were not statistically different between the groups (83 vs. $76 \%, p=0.52$ ). The existence of preoperative AF did not significantly affect post-LVAD thrombotic or hemorrhagic events in the univariate and multivariate analyses (HR 0.91, $p=0.87$, and HR $0.60, p=0.34$, respectively). On the contrary, patient age and no aspirin use at 1 month were significant risk factors $[51,52]$. A meta-analysis of 7 studies on 5,685 patients demonstrated that preoperative AF does not increase the risk of all-cause mortality, risk of thromboembolism, pump thrombosis or major bleedings after LVAD implantation in the 1-year follow-up but it was significantly associated with postoperative gastrointestinal bleeding [57]. Also other studies, based on the INTERMACS registry, did not confirm the increased rate of thromboembolic events or mortality in case of preoperative AF [58]. Kurihara et al. [59] compared 229 patients with preoperative $\mathrm{AF}$ and 297 patients without $\mathrm{AF}$ undergoing HM II or HVAD implantation. No significant difference was found in perioperative or long-term survival and postoperative stroke.

Enriquez et al. [4] performed an analysis to determine the effect of preoperative AF on outcomes in patients with HM II. Fifty patients out of 106 had preimplantation AF, and 5 patients developed it after 30 days. Thirty-six patients had PAF while 19 had PeAF. The latter were at increased risk for death or HF hospitalization when compared to the PAF or control 
group, and PeAF remained an independent predictor of the composite end point of death or HF hospitalization (HR 3.54; 95\% CI 1.52-8.25; $p<0.01$ ). PAF was not associated with increased risk of death, $\mathrm{HF}$ hospitalization, bleeding or thromboembolism. Moreover, although not significantly, peak $\mathrm{VO}_{2}$ during a cardiopulmonary exercise test was lower in PeAF than in patients with PAF or controls [4]. Such results point out that the right ventricle, which is mainly responsible for hemodynamic support in this population, is particularly sensitive, despite artificial support, to the hemodynamic effect of this arrhythmia. LVAD support leaves the left ventricular filling unaffected by AF, but RV filling and consequently cardiac output may still be compromised by loss of atrial contraction, especially in patients with poor RV function and pulmonary hypertension. In an analysis of 123 patients undergoing LVAD implantation performed by Koh et al. [60], 54.5\% had a history of AF with $28.3 \%$ of them having persistent or permanent forms. By univariate analysis, any form of AF was significantly associated with early right $\mathrm{HF}$ (odds ratio [OR] 2.18; 95\% CI 1.037-458; $p=0.04$ ), even if the statistical significance was lost when adjusting for age. After analyzing by type of AF patients with permanent forms were more likely to develop earlier right ventricular failure post implantation than other groups (OR 5.64; 95\% CI 1.12-28.40; $p=0.036$ ). Mortality was higher among LVAD patients with AF compared to those without AF (32 vs. 15\%, $p=0.03$ ) [60]. As shown by Deshmukh et al. [44], PeAF prior to LVAD leads to reduced survival when compared to preoperative AF or no-AF (1-year survival 63 vs. 43\%, $p=0.02$ ) and remains an independent predictor of mortality in multivariate analysis (HR 1.8; 95\% CI 1.0-3.0; $p=0.03$ ). Moreover, the increasing burden of AF, from no AF to persistent AF, seems to be directly correlated with increased mortality in a multivariate model (HR 1.2, 95\% CI 0.98-1.65; $p=$ 0.07). In a single-center study on 117 patients with permanent AF preoperatively compared with 205 patients in sinus rhythm (implanted with HVAD or HM II), AF had no influence on survival rate, risk of stroke, pump thrombosis and gastrointestinal bleeding at the 1-year follow up. In contrast, at the 2-year follow-up, the survival rate was significantly reduced in the AF group (HR $=1.48,95 \%$ CI 1.02-2.15; $p=0.038$ ) with increased incidence of right HF ( $p=0.008$ ), while the other end points remained not significantly different. Such results suggest that disease progression may be responsible for an increased mortality in the midterm $[61,62]$ (Table 1).

\section{AF after LVAD Implantation}

Postoperative AF (POAF) after LVAD (i.e., in the first 30 days) is one of the most common complications reported $[2,63,64]$. In 47 patients who underwent LVAD implantation without previous episodes of AF, POAF developed in $28 \%$ of patients at a mean $7.9 \pm 8.5$ days after surgery and the only predictor of its onset was obstructive lung disease. POAF was not associated with increased mortality, length of stay or thrombotic complication within 30 days. However, it was predictive of recurrent new $\mathrm{AF}$ (31 vs. 5.8\%) after 30 days from LVAD implantation. Also, POAF was associated with increased risk of ischemic stroke and device thrombosis during long-term follow-up $(p<0.05)$, independently from comorbidities [65]. As shown by Hawkins et al. [45], POAF was detected in 121 patients out of 689 patients without a history of AF. Development of new-onset AF was predominant in older patients, moderate-severe mitral regurgitation, history of stroke and concomitant tricuspid surgery. Moreover, it was associated with major morbidity (OR 2.5; $p=0.0004$ ), prolonged ventilation (OR 2.7; $p<0.0004$ ), unplanned right ventricular assist device (OR 2.9; $p<0.01$ ) and trend toward renal failure (OR $2.0 ; p<0.06)$. Not least, $\mathrm{POAF}$ was significantly associated with greater resource utilization (OR $2.2 ; p=0.007$ ) [45].

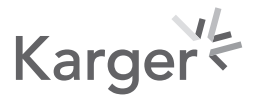




\begin{tabular}{l|l}
\hline Pulse 2020;8:2-14 \\
\hline DOI: 10.1159/000506600 & $\begin{array}{l}\text { @ 2020 S. Karger AG, Basel } \\
\text { www.karger.com/pls }\end{array}$ \\
\hline
\end{tabular}

Table 2. Summary of studies relating new-onset atrial fibrillation (AF) after implantation with thromboembolic events, bleeding and survival

\begin{tabular}{|c|c|c|c|c|}
\hline Study & $\begin{array}{l}\text { Incidence of AF after } \\
\text { implantation }\end{array}$ & Thromboembolic events & Bleeding & Survival \\
\hline $\begin{array}{l}\text { Enriquez } \\
\text { et al. [4], } 2014\end{array}$ & $\begin{array}{l}5 / 106(4.7 \% \text {, beyond } \\
30 \text { days })\end{array}$ & & $\begin{array}{l}\text { Significant } \\
\text { predictor of } \\
\text { bleeding }\end{array}$ & \\
\hline $\begin{array}{l}\text { Deshmukh } \\
\text { et al. [44], } 2017\end{array}$ & $\begin{array}{l}\text { 51/331 (15,4\%, } 14 \\
\text { within } 30 \text { days, } 37 \\
\text { beyond } 30 \text { days) }\end{array}$ & & & $\begin{array}{l}\text { Associated with worsened } \\
\text { survival }\end{array}$ \\
\hline $\begin{array}{l}\text { Hawkins } \\
\text { et al. [45], } 2018\end{array}$ & $121 / 1,064(17.6 \%)$ & $\begin{array}{l}\text { No significant difference in the } \\
\text { incidence of stroke }\end{array}$ & & $\begin{array}{l}\text { Associated with prolonged } \\
\text { ventilation, unplanned right } \\
\text { ventricular assist device, renal } \\
\text { failure, greater resource } \\
\text { utilization }\end{array}$ \\
\hline $\begin{array}{l}\text { Deshmukh et al. } \\
\text { [65], } 2017\end{array}$ & $13 / 47(28 \%)$ & $\begin{array}{l}\text { Not associated with stroke or device } \\
\text { thrombosis within } 30 \text { days; increased } \\
\text { risk of ischemic stroke and device } \\
\text { thrombosis in the long term (median } \\
330 \text { days) }\end{array}$ & & $\begin{array}{l}\text { No effect on 30-day or long-term } \\
\text { mortality (median } 330 \text { days) }\end{array}$ \\
\hline
\end{tabular}

The Japanese Mechanically Assisted Circulatory Support registry described de novo AF after LVAD implantation at the 1-year follow-up in 3 out of 140 patients previously in sinus rhythm [52]. In a sample of 331 patients followed for 330 days after LVAD implantation [44], 14 patients developed new-onset AF after 30 days, new-onset atrial flutter was documented in 31 patients, while POAF occurred in 37 patients. The same study showed that in $43 \%$ of patients with a history of AF before LVAD, no further evidence of the arrhythmia was evidenced during follow-up. Moreover, predictors of recurrent AF episodes in patients with prior AF were increasing age (OR 1.06; 95\% CI 1.03-1.08; $p<0.00001$ ), ischemic cardiomyopathy (OR 2.25; 95\% CI 1.43-3.57; $p=0.0005$ ) or coronary artery bypass graft (OR 1.60; 95\% CI 1.01-2.54; $p=0.046$ ), chronic obstructive pulmonary disease(OR 1.97; 95\% CI 1.21-3.23; $p=0.007$ ), thyroid disease (OR 1.70; 95\% CI 1.03$2.83 ; p=0.04$ ) or first-grade atrioventricular block (OR 2.35; 95\% CI 1.12-4.99; $p=0.02$ ). New-onset AF was prevalent with increasing age (OR 1.04; 95\% CI 1.01-1.07; $p=0.007$ ), creatinine (OR 1.40; 95\% CI 1.00-2.03; $p=0.049$ ) and history of chronic obstructive pulmonary disease (OR 2.20; 95\% CI 1.05-4.57; $p=0.03$ ). Development of AF in patients without prior history was associated with worse survival in a multivariate Cox regression analysis, and the result remained significant when postoperative AF was not included [44]. A small case series [66] demonstrated improvement of right ventricular failure after ablation of AFl in patients with LVADs, confirming the relevant implication of AF for right ventricular hemodynamics. Consequently, AF and LA volume could be used as parameters for the chronic optimization of LVADs. Enriquez et al. [4] showed that after LVAD implantation there was no significant bleeding event or difference in the INR at the time of the event between patients with no AF, PAF and PeAF, but development of new AF after LVAD was a significant predictor of bleeding (HR 3.63; 95\% CI 1.26-10.45; $p=0.02$ ) [4]. Among the three groups, there was no significant difference in the type of thromboembolism or in survival free from thromboembolism, and, in any type of AF, INR was higher than in patients without AF both at the time of thromboembolic event $(p=0.003)$ and for the previous 4 weeks ( $p=0.006$ ) [4] (Table 2). 


\begin{tabular}{l|l}
\hline Pulse 2020;8:2-14 \\
\hline DOI: 10.1159/000506600 & $\begin{array}{l}\text { @) 2020 S. Karger AG, Basel } \\
\text { www.karger.com/pls }\end{array}$ \\
\hline
\end{tabular}

Sisti et al.: Focus on Atrial Fibrillation in LVAD Patients

Table 3. Summary of the cited reports on therapeutic strategy for atrial fibrillation in LVAD patients

\begin{tabular}{|c|c|c|c|}
\hline Study & Subject & Patients & Findings \\
\hline $\begin{array}{l}\text { Noll et al. } \\
{[46], 2019}\end{array}$ & Rhythm control for atrial fibrillation & $166 / 238(70 \%)$ & $\begin{array}{l}\text { Patients treated with rhythm control (drugs or } \\
\text { electrical cardioversion) show no difference in } \\
\text { incidence of death, thromboembolism and } \\
\text { bleeding from those without rhythm control } \\
\text { exposure }\end{array}$ \\
\hline $\begin{array}{l}\text { Lewis et al. } \\
{[49], 2017}\end{array}$ & LAA occlusion during implantation & $18 / 47(38 \%)$ & $\begin{array}{l}\text { No significant reduction in thromboembolic } \\
\text { complications after } 3 \text {-year follow-up }\end{array}$ \\
\hline $\begin{array}{l}\text { Hottigoudar et al. [66], } \\
2013\end{array}$ & , Persistent atrial flutter ablation & 8 & $\begin{array}{l}\text { Transcatheter ablation of atrial flutter improves } \\
\text { symptoms of right heart failure }\end{array}$ \\
\hline $\begin{array}{l}\text { Maury et al. } \\
{[67], 2010}\end{array}$ & $\begin{array}{l}\text { Radiofrequency ablation of atrial } \\
\text { fibrillation }\end{array}$ & 1 & $\begin{array}{l}\text { First case of radiofrequency ablation of atrial } \\
\text { fibrillation; no interference with the functioning of } \\
\text { the device }\end{array}$ \\
\hline $\begin{array}{l}\text { Jennings et al. } \\
\text { [68], } 2012\end{array}$ & $\begin{array}{l}\text { Effect of LVAD on warfarin pharmaco- } \\
\text { dynamic }\end{array}$ & 13 & $\begin{array}{l}\text { Response to warfarin is not changed shortly after } \\
\text { implantation }\end{array}$ \\
\hline $\begin{array}{l}\text { Terrovitis et al. [70], } \\
2015\end{array}$ & $\begin{array}{l}\text { Use of dabigatran as second-line anti- } \\
\text { coagulation option }\end{array}$ & 7 & $\begin{array}{l}\text { No significant difference from warfarin in rate of } \\
\text { stroke, systemic embolism, device thrombosis, } \\
\text { life-threatening bleeding }(1,564 \pm 292 \text { days })\end{array}$ \\
\hline $\begin{array}{l}\text { Pollari et al. } \\
{[71], 2016}\end{array}$ & $\begin{array}{l}\text { Use of apixaban as second-line antico- } \\
\text { agulation option after recurrent GI } \\
\text { bleeding }\end{array}$ & 1 & $\begin{array}{l}\text { No episodes of thromboembolism or pump throm- } \\
\text { bosis in 1-year follow-up }\end{array}$ \\
\hline $\begin{array}{l}\text { Deshmukh et al. [73], } \\
2018\end{array}$ & LAA occlusion during implantation & $36 / 102(35 \%)$ & $\begin{array}{l}\text { Significant reduction of thromboembolic events } \\
\text { ( } 302 \text { days) independently from preoperative atrial } \\
\text { fibrillation }\end{array}$ \\
\hline $\begin{array}{l}\text { Anwer et al. } \\
{[74], 2018}\end{array}$ & $\begin{array}{l}\text { Impact of preoperative atrial fibril- } \\
\text { lation on tricuspid regurgitation after } \\
\text { implantation }\end{array}$ & $52 / 137(38 \%)$ & $\begin{array}{l}\text { Significant association with early progression of } \\
\text { tricuspid regurgitation after implantation }\end{array}$ \\
\hline
\end{tabular}

LVAD, left ventricular assist device; LAA, left atrial appendage; GI, gastrointestinal.

\section{Therapeutic Perspectives for AF in LVAD Patients}

Authors supporting the increased mortality given by AF, especially PeAF, support also the benefit from an aggressive rhythm control strategy which could be performed through Cryo-Maze at the time of implantation or with stronger antiarrhythmic drugs or catheter ablation [4]. In a case series of 8 patients with HM II in whom poorly controlled atrial flutter after implantation had led to right HF, successful ablation led to complete resolution of symptoms. Another case report showed the same result after segmental pulmonary vein isolation in poorly controlled AF [66, 67]. According to Noll et al. [46] in a retrospective analysis of 418 patients over 12 years, rhythm control by ablation, maze or drugs is not associated with clinical outcome in terms of mortality, thromboembolism or bleeding. When warfarin is administered previously to implantation, the improvement of hepatic perfusion by the device can increase synthesis of vitamin K-dependent clotting factors and alter the pharmacodynamic response to this drug [68]. When a direct oral anticoagulant is used before implantation, switching to warfarin after surgery is the actual recommendation [69]. However, there are small studies in which warfarin was interrupted for serious anticoagulation-related events (with in-range INR) and replaced with dabigatran. Similar rates of thromboembolic events and bleedings were observed under dabigatran and warfarin, and the rates of major 
non-life-threatening bleeding were significantly higher with warfarin than with dabigatran [70]. A case report also reported the use of apixaban in an LVAD patient after gastrointestinal bleeding due to warfarin and showed the same results [71]. According to some authors, left atrial appendage (LAA) occlusion can be considered in all patients with thrombus detected in the LAA. This procedure could also be considered in patients with AF, at high risk for bleeding and an urgent need to stop anticoagulation [72]. Deshmukh et al. [73] investigated the effect on thromboembolic events of LAA occlusion at the time of LVAD implantation in 36 patients out of 102 (52.7\% of whom had preoperative AF). The procedure was associated with a significantly decreased risk of thromboembolic events during follow-up, also after adjustment for age, sex, hypertension and history of AF (HR 0.27; 95\% CI 0.08-0.95; $p=0.04$ ). No difference was found concerning length of stay, incidence of postoperative AF or long-term mortality [73]. The same results were found in a smaller cohort of 47 patients by Lewis et al. [49] with a lower INR goal. In a study by Xuereb et al. [55] however, AF did not increase the risk of stroke or device thrombosis in LVAD patients, and for this reason the author stated that ligation of the LAA did not minimize the thromboembolic risk and could expose to complications such as bleeding of the ligation site, injury to the heart or its mobilization without reaching a benefit. It is currently under debate whether tricuspid regurgitation should be corrected at the time of implantation to reduce the probability of right HF, or whether the mechanical unloading is enough to improve right heart hemodynamic and the resultant tricuspid regurgitation. Anwer et al. [74] observed a significant gradual worsening of tricuspid regurgitation after implantation in 137 patients during a 5-year follow-up; in particular, this progression worsened in patients with preoperative AF $(n=52)$, probably due to atrial remodeling and enlargement of the tricuspid annulus [74-77] (Table 3).

\section{Conclusion}

The relevance of AF in patients with LVAD is clinically and epidemiologically significant. $\mathrm{AF}$ monitoring after implantation suggests the adequate/inadequate unloading status since left chamber remodeling is followed by a reduction of the arrhythmic burden. Among all types of preoperative $\mathrm{AF}$, peAF is associated with worse outcomes and acts as predictor of mortality or HF hospitalization in the long term. New-onset AF after implantation is associated with several comorbidities, and it is also a significant predictor of bleeding, while thromboembolic events are comparable to no-AF groups, although with higher INR levels. Rhythm control may play a pivotal role in modifying prognosis of LVAD patients, and transcatheter pulmonary vein isolation should be considered previously to implantation. Different strategies of anticoagulation and LAA occlusion are leading to promising results in the reduction of thromboembolic events even if indications need confirmation. Overall, management of AF in the perioperative setting of patients addressed to LVAD needs a comprehensive evaluation of the arrhythmic burden, thromboembolic/bleeding risk and prognostic impact, since for each clinical scenario a different therapeutic option with different outcome could be selected.

\section{Acknowledgment}

We thank Luca Regnini for the useful support in improving the manuscript.

\section{Disclosure Statement}

All the authors declare that they have no conflict of interest.

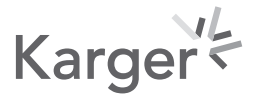




\begin{tabular}{l|l}
\hline Pulse 2020;8:2-14 \\
\hline DOI: 10.1159/000506600 & $\begin{array}{l}\text { @ 2020 S. Karger AG, Basel } \\
\text { www.karger.com/pls }\end{array}$ \\
\hline
\end{tabular}

Sisti et al.: Focus on Atrial Fibrillation in LVAD Patients

\section{Funding Sources}

This research received no specific grant from any funding agency in the public, commercial or not-forprofit sectors.

\section{Author Contributions}

All authors contributed equally to this work.

\section{References}

1 Crespo-Leiro MG, Metra M, Lund LH, Milicic D, Costanzo MR, Filippatos G, et al. Advanced heart failure: a position statement of the Heart Failure Association of the European Society of Cardiology. Eur J Heart Fail. 2018 Nov;20(11):1505-35.

2 Hickey KT, Garan H, Mancini DM, Colombo PC, Naka Y, Sciacca RR, et al. Atrial Fibrillation in Patients With Left Ventricular Assist Devices: Incidence, Predictors, and Clinical Outcomes. JACC Clin Electrophysiol. 2016 Dec;2(7):793-8.

3 Kadado AJ, Akar JG, Hummel JP. Arrhythmias after left ventricular assist device implantation: incidence and management. Trends Cardiovasc Med. 2018 Jan;28(1):41-50.

4 Enriquez AD, Calenda B, Gandhi PU, Nair AP, Anyanwu AC, Pinney SP. Clinical impact of atrial fibrillation in patients with the HeartMate II left ventricular assist device. J Am Coll Cardiol. 2014 Nov;64(18):1883-90.

5 Lindenfeld J, Feldman AM, Saxon L, Boehmer J, Carson P, Ghali JK, et al. Effects of cardiac resynchronization therapy with or without a defibrillator on survival and hospitalizations in patients with New York Heart Association class IV heart failure. Circulation. 2007 Jan;115(2):204-12.

6 Piccini JP, Allen LA. Heart Failure Complicated by Atrial Fibrillation: Don't Bury the Beta-Blockers Just Yet. JACC Heart Fail. 2017 Feb;5(2):107-9.

7 Mamas MA, Caldwell JC, Chacko S, Garratt CJ, Fath-Ordoubadi F, Neyses L. A meta-analysis of the prognostic significance of atrial fibrillation in chronic heart failure. Eur J Heart Fail. 2009 Jul;11(7):676-83.

8 Trulock KM, Narayan SM, Piccini JP. Rhythm control in heart failure patients with atrial fibrillation: contemporary challenges including the role of ablation. J Am Coll Cardiol. 2014 Aug;64(7):710-21.

9 Olsson LG, Swedberg K, Ducharme A, Granger CB, Michelson EL, McMurray JJ, et al.; CHARM Investigators. Atrial fibrillation and risk of clinical events in chronic heart failure with and without left ventricular systolic dysfunction: results from the Candesartan in Heart failure-Assessment of Reduction in Mortality and morbidity (CHARM) program. J Am Coll Cardiol. 2006 May;47(10):1997-2004.

10 Ziff OJ, Carter PR, McGowan J, Uppal H, Chandran S, Russell S, et al. The interplay between atrial fibrillation and heart failure on long-term mortality and length of stay: insights from the United Kingdom ACALM registry. Int J Cardiol. 2018 Feb;252:117-21.

11 Santhanakrishnan R, Wang N, Larson MG, Magnani JW, McManus DD, Lubitz SA, et al. Atrial Fibrillation Begets Heart Failure and Vice Versa: Temporal Associations and Differences in Preserved Versus Reduced Ejection Fraction. Circulation. 2016 Feb;133(5):484-92.

12 Daoud EG, Weiss R, Bahu M, Knight BP, Bogun F, Goyal R, et al. Effect of an irregular ventricular rhythm on cardiac output. Am J Cardiol. 1996 Dec;78(12):1433-6.

13 Prabhu S, Voskoboinik A, Kaye DM, Kistler PM. Atrial Fibrillation and Heart Failure - Cause or Effect? Heart Lung Circ. 2017 Sep;26(9):967-74.

14 Kotecha D, Piccini JP. Atrial fibrillation in heart failure: what should we do? Eur Heart J. 2015 Dec;36(46): 3250-7.

15 Pastore MC, Mandoli GE, Aboumarie HS, Santoro C, Bandera F, D’Andrea A, et al; Working Group of Echocardiography of the Italian Society of Cardiology. Basic and advanced echocardiography in advanced heart failure: an overview. Heart Fail Rev. 2019 Oct. DOI: 10.1007/s10741-019-09865-3.

16 Burashnikov A, Di Diego JM, Sicouri S, Doss MX, Sachinidis A, Barajas-Martínez H, et al. A temporal window of vulnerability for development of atrial fibrillation with advancing heart failure. Eur J Heart Fail. 2014 Mar; 16(3):271-80.

17 Dries DL, Exner DV, Gersh BJ, Domanski MJ, Waclawiw MA, Stevenson LW. Atrial fibrillation is associated with an increased risk for mortality and heart failure progression in patients with asymptomatic and symptomatic left ventricular systolic dysfunction: a retrospective analysis of the SOLVD trials. Studies of Left Ventricular Dysfunction. J Am Coll Cardiol. 1998 Sep;32(3):695-703.

18 Al Halabi S, Qintar M, Hussein A, Alraies MC, Jones DG, Wong T, et al. Catheter Ablation for Atrial Fibrillation in Heart Failure Patients: A Meta-Analysis of Randomized Controlled Trials. JACC Clin Electrophysiol. 2015 Jun;1(3):200-9.

19 Marrouche NF, Brachmann J, Andresen D, Siebels J, Boersma L, Jordaens L, et al.; CASTLE-AF Investigators. Catheter Ablation for Atrial Fibrillation with Heart Failure. N Engl J Med. 2018 Feb;378(5):417-27.

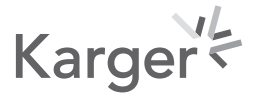




\begin{tabular}{l|l}
\hline Pulse 2020;8:2-14 \\
\hline DOI: 10.1159/000506600 & $\begin{array}{l}\text { @ 2020 S. Karger AG, Basel } \\
\text { www.karger.com/pls }\end{array}$ \\
\hline
\end{tabular}

Sisti et al.: Focus on Atrial Fibrillation in LVAD Patients

20 Ponikowski P, Voors AA, Anker SD, Bueno H, Cleland JG, Coats AJ, et al.; ESC Scientific Document Group. 2016 ESC Guidelines for the diagnosis and treatment of acute and chronic heart failure: the Task Force for the diagnosis and treatment of acute and chronic heart failure of the European Society of Cardiology (ESC)Developed with the special contribution of the Heart Failure Association (HFA) of the ESC. Eur Heart J. 2016 Jul;37 (27): 2129-200.

21 Aissaoui N, Morshuis M, Maoulida H, Salem JE, Lebreton G, Brunn M, et al. Management of end-stage heart failure patients with or without ventricular assist device: an observational comparison of clinical and economic outcomes. Eur J Cardiothorac Surg. 2018 Jan;53(1):170-7.

22 Gustafsson F, Rogers JG. Left ventricular assist device therapy in advanced heart failure: patient selection and outcomes. Eur J Heart Fail. 2017 May;19(5):595-602.

23 Moazami N, Fukamachi K, Kobayashi M, Smedira NG, Hoercher KJ, Massiello A, et al. Axial and centrifugal continuous-flow rotary pumps: a translation from pump mechanics to clinical practice. J Heart Lung Transplant. 2013 Jan;32(1):1-11.

24 Mehra MR, Uriel N, Naka Y, Cleveland JC Jr, Yuzefpolskaya M, Salerno CT, et al.; MOMENTUM 3 Investigators. A Fully Magnetically Levitated Left Ventricular Assist Device - Final Report. N Engl J Med. 2019 Apr;380(17): 1618-27.

25 Feldman D, Pamboukian SV, Teuteberg JJ, Birks E, Lietz K, Moore SA, et al.; International Society for Heart and Lung Transplantation. The 2013 International Society for Heart and Lung Transplantation Guidelines for mechanical circulatory support: executive summary. J Heart Lung Transplant. 2013 Feb;32(2):157-87.

26 Kirklin JK, Pagani FD, Kormos RL, Stevenson LW, Blume ED, Myers SL, et al. Eighth annual INTERMACS report: special focus on framing the impact of adverse events. J Heart Lung Transplant. 2017 0ct;36(10):1080-6.

27 Russell SD, Miller LW, Pagani FD. Advanced heart failure: a call to action. Congest Heart Fail. 2008 Nov-Dec; 14(6):316-21.

28 Schmitto JD, Zimpfer D, Fiane AE, Larbalestier R, Tsui S, Jansz P, et al. Long-term support of patients receiving a left ventricular assist device for advanced heart failure: a follow-up analysis of the Registry to Evaluate the HeartWare Left Ventricular Assist System. Eur J Cardiothorac Surg. 2016 Nov;50(5):834-8.

29 Koliopoulou A, McKellar SH, Rondina M, Selzman CH. Bleeding and thrombosis in chronic ventricular assist device therapy: focus on platelets. Curr Opin Cardiol. 2016 May;31(3):299-307.

30 Pratt AK, Shah NS, Boyce SW. Left ventricular assist device management in the ICU. Crit Care Med. 2014 Jan; 42(1):158-68.

31 Suarez J, Patel CB, Felker GM, Becker R, Hernandez AF, Rogers JG. Mechanisms of bleeding and approach to patients with axial-flow left ventricular assist devices. Circ Heart Fail. 2011 Nov;4(6):779-84.

32 Wilson SR, Givertz MM, Stewart GC, Mudge GH Jr. Ventricular assist devices the challenges of outpatient management. J Am Coll Cardiol. 2009 Oct;54(18):1647-59.

33 Aissaoui N, Börgermann J, Gummert J, Morshuis M. HeartWare continuous-flow ventricular assist device thrombosis: the Bad Oeynhausen experience. J Thorac Cardiovasc Surg. 2012 Apr;143(4):e37-9.

34 Nguyen AB, Uriel N, Adatya S. New Challenges in the Treatment of Patients With Left Ventricular Support: LVAD Thrombosis. Curr Heart Fail Rep. 2016 Dec;13(6):302-9.

35 Kirchhof P, Benussi S, Kotecha D, Ahlsson A, Atar D, Casadei B, et al.; ESC Scientific Document Group. 2016 ESC Guidelines for the management of atrial fibrillation developed in collaboration with EACTS. Eur Heart J. 2016 Oct;37(38):2893-962.

36 Pedde D, Soltani S, Stein J, Tsyganenko D, Müller M, Schönrath F, et al. Impact of preoperative atrial fibrillation on thromboembolic events and pump thrombosis in long-term left ventricular assist device therapy. Eur J Cardiothorac Surg. 2020 Feb;57(2):325-30.

37 Boyle AJ, Russell SD, Teuteberg JJ, Slaughter MS, Moazami N, Pagani FD, et al. Low thromboembolism and pump thrombosis with the HeartMate II left ventricular assist device: analysis of outpatient anti-coagulation. J Heart Lung Transplant. 2009 Sep;28(9):881-7.

38 Estep JD, Trachtenberg BH, Loza LP, Bruckner BA. Continuous flow left ventricular assist devices: shared care goals of monitoring and treating patients. Methodist DeBakey Cardiovasc J. 2015 Jan-Mar;11(1):33-44.

39 Koene RJ, Win S, Naksuk N, Adatya SN, Rosenbaum AN, John R, et al. HAS-BLED and $\mathrm{CHA}_{2} \mathrm{DS}_{2}$-VASc scores as predictors of bleeding and thrombotic risk after continuous-flow ventricular assist device implantation. J Card Fail. 2014 Nov;20(11):800-7.

40 Miller LW, Pagani FD, Russell SD, John R, Boyle AJ, Aaronson KD, et al.; HeartMate II Clinical Investigators. Use of a continuous-flow device in patients awaiting heart transplantation. N Engl J Med. 2007 Aug;357(9):885-96.

41 van Walraven C, Jennings A, Oake N, Fergusson D, Forster AJ. Effect of study setting on anticoagulation control: a systematic review and metaregression. Chest. 2006 May;129(5):1155-66.

42 Boehme AK, Pamboukian SV, George JF, Beasley TM, Kirklin JK, Tallaj J, et al. Anticoagulation Control in Patients With Ventricular Assist Devices. ASAIO J. 2017 Nov/Dec;63(6):759-65.

43 Jennings D, McDonnell J, Schillig J. Assessment of long-term anticoagulation in patients with a continuous-flow left-ventricular assist device: a pilot study. J Thorac Cardiovasc Surg. 2011 Jul;142(1):e1-2.

44 Deshmukh A, Kim G, Burke M, Anyanwu E, Jeevanandam V, Uriel N, et al. Atrial arrhythmias and electroanatomical remodeling in patients with left ventricular assist devices. J Am Heart Assoc. 2017 Mar;6(3):1-9.

45 Hawkins RB, Mehaffey JH, Guo A, Charles EJ, Speir AM, Rich JB, et al.; Virginia Cardiac Services Quality Initiative. Postoperative atrial fibrillation is associated with increased morbidity and resource utilization after left ventricular assist device placement. J Thorac Cardiovasc Surg. 2018 Oct;156(4):1543-1549.e4.

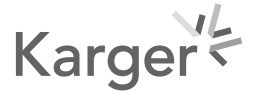




\begin{tabular}{l|l}
\hline Pulse 2020;8:2-14 \\
\hline DOI: 10.1159/000506600 & $\begin{array}{l}\text { @ 2020 S. Karger AG, Basel } \\
\text { www.karger.com/pls }\end{array}$ \\
\hline
\end{tabular}

Sisti et al.: Focus on Atrial Fibrillation in LVAD Patients

46 Noll AE, Adewumi J, Amuthan R, Gillombardo CB, Mannan Z, Kiehl EL, et al. Atrial Tachyarrhythmias Among Patients With LeftVentricularAssistDevices:Prevalence,Clinical Outcomes, and Impact of Rhythm Control Strategies. JACC Clin Electrophysiol. 2019 Apr;5(4):459-66.

47 Leung DY, Black IW, Cranney GB, Hopkins AP, Walsh WF. Prognostic implications of left atrial spontaneous echo contrast in nonvalvular atrial fibrillation. J Am Coll Cardiol. 1994 Sep;24(3):755-62.

48 Fatkin D, Kelly RP, Feneley MP. Relations between left atrial appendage blood flow velocity, spontaneous echocardiographic contrast and thromboembolic risk in vivo. J Am Coll Cardiol. 1994 Mar;23(4):961-9.

49 Lewis RS, Wang L, Spinelli KJ, Ott GY, Abraham J. Surgical occlusion of the left atrial appendage and thromboembolic complications in patients with left ventricular assist devices. J Heart Lung Transplant. 2017 May; 36(5):586-8.

50 Uriel N, Sayer G, Addetia K, Fedson S, Kim GH, Rodgers D, et al. Hemodynamic Ramp Tests in Patients With Left Ventricular Assist Devices. JACC Heart Fail. 2016 Mar;4(3):208-17.

51 Imamura T, Chung B, Nguyen A, Sayer G, Uriel N. Clinical implications of hemodynamic assessment during left ventricular assist device therapy. J Cardiol. 2018 Apr;71(4):352-8.

52 Imamura T, Kinugawa K, Ono M, Kinoshita O, Fukushima N, Shiose A, et al. Implication of preoperative existence of atrial fibrillation on hemocompatibility-related adverse events during left ventricular assist device support. Circ J. 2019 May;83(6):1286-92.

53 Clark DM, Plumb VJ, Epstein AE, Kay GN. Hemodynamic effects of an irregular sequence of ventricular cycle lengths during atrial fibrillation. J Am Coll Cardiol. 1997 Oct;30(4):1039-45.

54 Naito M, David D, Michelson EL, Schaffenburg M, Dreifus LS. The hemodynamic consequences of cardiac arrhythmias: evaluation of the relative roles of abnormal atrioventricular sequencing, irregularity of ventricular rhythm and atrial fibrillation in a canine model. Am Heart J. 1983 Aug;106(2):284-91.

55 Xuereb L, Go PH, Kaur B, Akrawe S, Nemeh HW, Borgi J, et al. Impact of Preoperative Atrial Fibrillation on Postoperative Thromboembolic Events After Left Ventricular Assist Device Implantation. Ann Thorac Surg. 2016 Nov;102(5):1543-9.

56 Stulak JM, Deo S, Schirger J, Aaronson KD, Park SJ, Joyce LD, et al. Preoperative atrial fibrillation increases risk of thromboembolic events after left ventricular assist device implantation. Ann Thorac Surg. 2013 Dec;96(6):2161-7.

57 Usman MS, Ahmed S, Yamani N, Akhtar T, Asmi N, Siddiqi TJ, et al. Meta-Analysis of the Effect of Preoperative Atrial Fibrillation on Outcomes After Left Ventricular Assist Device Implantation. Am J Cardiol. 2019 Jul; 124(1):158-62.

58 Xia Y, Stern D, Friedmann P, Goldstein D. Preoperative atrial fibrillation may not increase thromboembolic events in left ventricular assist device recipients on midterm follow-up. J Heart Lung Transplant. 2016 Jul; 35(7):906-12.

59 Kurihara C, Critsinelis A, Kawabori M, Sugiura T, Civitello AB, Morgan JA. Effect of preoperative atrial fibrillation on patients with chronic heart failure who undergo long-term continuous-flow LVAD implantation. ASAIO J. 2018 Sep/Oct;64(5):594-600.

60 Koh S, Braun OO, Brambatti M, Kim P, Tran H, Pretorius V, et al. Atrial fibrillation is associated with early right ventricular failure post-LVAD. J Heart Lung Transplant. 2018;37(4):S131.

61 Oezpeker CU, Morshuis M, Schoenbrodt M, Zittermann A, Gummert J. Permanent atrial fibrillation and 1-year clinical outcome in patients with left ventricular assist device implants. J Heart Lung Transplant. 2016 Apr; 35(4):S150.

62 Oezpeker C, Zittermann A, Pühler T, Ensminger S, Gummert JF, Morshuis M. Permanent Atrial Fibrillation and 2 Year Clinical Outcomes in Patients with a Left Ventricular Assist Device Implant. ASAIO J. 2017 Jul/Aug; 63(4):419-24.

63 Brisco MA, Sundareswaran KS, Milano CA, Feldman D, Testani JM, Ewald GA, et al.; HeartMate II Clinical Investigators. Incidence, risk, and consequences of atrial arrhythmias in patients with continuous-flow left ventricular assist devices. J Card Surg. 2014 Jul;29(4):572-80.

64 Genovese EA, Dew MA, Teuteberg JJ, Simon MA, Kay J, Siegenthaler MP, et al. Incidence and patterns of adverse event onset during the first 60 days after ventricular assist device implantation. Ann Thorac Surg. 2009 0ct; 88(4):1162-70.

65 Deshmukh A, Bhatia A, Anyanwu E, Uriel N, Tung R, Jeevanandam V, et al. Incidence, predictors, and outcome of postoperative atrial fibrillation in patients receiving continuous flow left ventricular assist devices. J Am Coll Cardiol. 2017;69(11):461.

66 Hottigoudar RU, Deam AG, Birks EJ, McCants KC, Slaughter MS, Gopinathannair R. Catheter ablation of atrial flutter in patients with left ventricular assist device improves symptoms of right heart failure. Congest Heart Fail. 2013 Jul-Aug;19(4):165-71.

67 Maury P, Delmas C, Trouillet C, Slaughter MS, Lairez O, Galinier M, et al. First experience of percutaneous radiofrequency ablation for atrial flutter and atrial fibrillation in a patient with HeartMate II left ventricular assist device. J Interv Card Electrophysiol. 2010 Oct;29(1):63-7.

68 Jennings DL, Brewer R, Williams C. Impact of continuous flow left ventricular assist device on the pharmacodynamic response to warfarin early after implantation. Ann Pharmacother. 2012 Sep;46(9):1266-7.

69 Baumann Kreuziger LM, Kim B, Wieselthaler GM. Antithrombotic therapy for left ventricular assist devices in adults: a systematic review. J Thromb Haemost. 2015 Jun;13(6):946-55.

70 Terrovitis JV, Ntalianis A, Kapelios CJ, Vakrou S, Diakos N, Katsaros L, et al. Dabigatran etexilate as second-line therapy in patients with a left ventricular assist device. Hellenic J Cardiol. 2019 Oct;56(1):20-5.

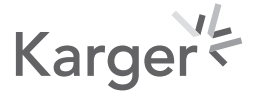


71 Pollari F, Fischlein T, Fittkau M, Santarpino G. Anticoagulation with apixaban in a patient with a left ventricular assist device and gastrointestinal bleeding: A viable alternative to warfarin? J Thorac Cardiovasc Surg. 2016 Apr;151(4):e79-81.

72 Ho G, Braun OÖ, Adler ED, Feld GK, Pretorius VG, Birgersdotter-Green U. Management of Arrhythmias and Cardiac Implantable Electronic Devices in Patients With Left Ventricular Assist Devices. JACC Clin Electrophysiol. 2018 Jul;4(7):847-59.

73 Deshmukh A, Bhatia A, Sayer GT, Kim G, Raikhelkar J, Imamura T, et al. Left Atrial Appendage Occlusion With Left Ventricular Assist Device Decreases Thromboembolic Events. Ann Thorac Surg. 2019 Apr;107(4):1181-6.

74 Anwer LA, Tchantchaleishvili V, Poddi S, Daly RC, Joyce LD, Kushwaha SS, et al. Atrial fibrillation should guide prophylactic tricuspid procedures during left ventricular assist device implantation. ASAIO J. 2018 Sep/Oct; 64(5):586-93.

75 Rao V, Slater JP, Edwards NM, Naka Y, Oz MC. Surgical management of valvular disease in patients requiring left ventricular assist device support. Ann Thorac Surg. 2001 May;71(5):1448-53.

76 Morgan JA, Paone G, Nemeh HW, Murthy R, Williams CT, Lanfear DE, et al. Impact of continuous-flow left ventricular assist device support on right ventricular function. J Heart Lung Transplant. 2013 Apr;32(4):398403.

77 Lee S, Kamdar F, Madlon-Kay R, Boyle A, Colvin-Adams M, Pritzker M, et al. Effects of the HeartMate Il continuous-flow left ventricular assist device on right ventricular function. J Heart Lung Transplant. 2010 Feb; 29(2):209-15. 